\title{
Association between dental pain and absenteeism among public workers from Southeastern Brazil*
}

\author{
Associação entre dor de dente e absenteísmo em funcionários públicos do sudeste do Brasil \\ Maria Helena Monteiro de Barros Miottoํ, Wadson José Gonçalves Lima², Ludmilla Awad Barcellos ${ }^{3}$
}

${ }^{*}$ Received from Federal Univesrity of Espírito Santo, Vila Velha, ES, Brazil.

DOI 10.5935/1806-0013.20140038

\section{ABSTRACT}

BACKGROUND AND OBJECTIVES: Studies carried out worldwide have shown that the incidence of dental pain is one reason leading people to look for dental services and that it impairs quality of life. This study aimed at observing the prevalence of dental pain, pain-related absenteeism and possible associations with sociodemographic characteristics.

METHODS: This was an analytical, observational and transversal study using a randomized sample of 312 public servants obtained from a universe of 994 employees of the City Hall of Marataízes, ES. A structured script with 27 items was used for data collection, which was carried out between May and June 2009, by three qualified servants. Chi-square and Fisher Exact tests were used to compare dental pain percentages and absenteeism to sociodemographic factors.

RESULTS: The prevalence of dental pain among employees was $57.0 \%$, with higher prevalence among those with socioeconomic condition $\mathrm{C} / \mathrm{D} / \mathrm{E}(\mathrm{OR}=1.560)$. From those reporting dental pain, $17.8 \%$ have missed work, with higher prevalence of those of socioeconomic condition $\mathrm{C} / \mathrm{D} / \mathrm{E}(\mathrm{OR}=$ 3.816) and with incomplete high school ( $\mathrm{OR}=2.298)$.

CONCLUSION: High dental pain prevalence was observed and enough to produce absenteeism, with higher frequency among workers of less favored economic classes and with lower education level.

Keywords: Absenteeism, Dental pain, Worker's health.

\footnotetext{
1. Federal University of Espírito Santo, Vitória, ES, Brazil

2. Brazilian Association of Dentistry, Vitória, ES, Brazil.

3. Vila Velha Universtiy, Vila Velha, ES, Brazil.

Submitted in May 23, 2014.

Accepted for publication in August 21, 2014.

Conflict of interests: none.

Correspondence to:

Maria Helena Monteiro de Barros Miotto

Av. Marechal Campos 1468 - Maruípe

29040-091 Vitória, ES, Brasil.

E-mail: mhmiotto@terra.com.br

(C) Sociedade Brasileira para o Estudo da Dor
}

\section{RESUMO}

JUSTIFICATIVA E OBJETIVOS: Pesquisas realizadas em todo o mundo demonstram que a ocorrência de dor de dente é uma das razóes que levam as pessoas a procurar o serviço odontológico, comprometendo a qualidade de vida. O objetivo deste estudo foi verificar a prevalência da dor dentária, absenteísmo motivado pela dor e possíveis associaçóes com características sociodemográficas.

MÉTODOS: Estudo analítico, observacional, transversal utilizou uma amostra aleatória de 312 servidores obtida de um universo de 994 funcionários da Prefeitura do município de Marataízes, ES. Foi utilizado um roteiro estruturado com 27 itens para a coleta de dados, realizada entre maio e junho de 2009, por três servidoras treinadas. Para comparaçáo dos percentuais de dor dentária e absenteísmo com os fatores sociodemográficos foram utilizados os testes Qui-quadrado e Exato de Fisher.

RESULTADOS: A prevalência de dor dentária entre os funcionários foi de $57,0 \%$, com maior prevalência naqueles com condição socioeconômica $\mathrm{C} / \mathrm{D} / \mathrm{E}(\mathrm{OR}=1,560)$. Dos que sentiram dor dentária, $17,8 \%$ faltaram ao trabalho, com maior prevalência para os de condição socioeconômica $\mathrm{C} / \mathrm{D} / \mathrm{E}$ $(\mathrm{OR}=3,816)$ e com escolaridade até o ensino médio incompleto $(\mathrm{OR}=2,298)$.

CONCLUSÃO: Alta prevalência de dor de dente foi observada e suficiente para produzir absenteísmo, com maior frequência em trabalhadores inseridos nas classes econômicas menos favorecidas e com menor escolaridade.

Descritores: Absenteísmo, Odontalgia, Saúde do trabalhador.

\section{INTRODUCTION}

Epidemiological studies show that pain is the primary reason for looking for health services and is one of the major causes of human suffering, impairing quality of life (QL) and psychosocial and economic status ${ }^{1}$.

Dental pain is one of the most common pains affecting humankind. It is responsible for a large number of work losses. Absences from work due to health problems reflect incapacity to perform labor activities ${ }^{2}$.

Absenteeism caused by oral problems is poorly studied in Brazil. There are no updated data on the number of lost working days due to dental pain, in national, state and municipal lev- 
els. There is also no information about the burden brought by such absences, such as the psychosocial impact for workers. There are two types of absenteeism: type 1 is characterized by absence from work; type 2 is characterized by physical presence with individuals working with pain ${ }^{3}$.

Dental problems may produce pain, discomfort and generate signs and symptoms, which go from decreased attention to work, to absence, in addition to social behaviors of isolation. This fact reaffirms the need for and the importance of dentists (D) participating in multidisciplinary teams ${ }^{3}$.

The compartmentalization which sees the mouth separated from the body is outdated. It is impossible to talk about integral workers' health attention without inserting Dentistry actions, which should be carried out within Occupational Health Medical Control Programs (OHMCP) by duly qualified Ds to deal with the specificity of oral health and work relationship 5 . The proposal of legislative bill $422 / 2007$ is based on this understanding and tries to contribute to close the existing gap, promoting the expansion of the number of actions aimed at preventing and assisting occupational diseases, with incorporation of Labor Dentistry actions. This is the only way for companies to comply with their social duty of promoting integral health assistance to their workers ${ }^{6}$.

Oral problems may directly impact professional performance. Because labor health promotion programs have a limited number of specific actions for oral health, there is the need to implement an oral health promotion protocol within companies. The implementation of such program would avoid absenteeism and decrease in productivity. Workers' oral health teams should orient their actions to promote health ${ }^{7}$.

This study aimed at measuring the frequency of dental pain in the last six months, and the possible occurrence of absenteeism caused by toothache and associations with sociodemographic variables of employees of the local government of Marataízes, ES.

\section{METHODS}

This is a transversal study with representative sample of local government workers of a resort to the South of the State, 200 $\mathrm{km}$ far from the capital. Parameters used for sample calculation were: expected prevalence of $35 \%$ - results found in studies carried out in the region - confidence level of $95 \%$, error of $5 \%$ and $n=994$. Calculation has resulted in a sample of 260 employees plus 52 more individuals, considering a possible loss of up to $20 \%$. The study has used a randomized sample of 312 employees. Those in maternal or medical leave were excluded from the study.

Data were collected by means of a validated questionnaire with 27 items regarding sociodemographic characteristics, need for total or partial prosthesis, dentition status (presence or total absence of teeth), dental pain, absenteeism, and type of service used for treatment.

Scripts were used as standardized interviews and were applied by three trained interviewers, non-participant public servants, assuring cultural, economic and social equivalence with respondents, between May and June 2009.

Chi-square and Fisher Exact tests were used to check possible associations. Significance level was 5\%. Odds Ratio (OR) and respective Confidence Intervals were calculated to check association power. Research was carried out according to ethical principles and was approved by the Research Ethics Committee, Federal University of Espirito Santo in March 24, 2009, protocol 023/09. All participants have signed the Free and Informed Consent Term.

\section{RESULTS}

Final sample was made up of 286 employees, above the original calculation $(n=252)$. There has been predominance of $\mathrm{fe}$ males (64\%), young individuals, $65 \%$ below 40 years of age, and $61.2 \%$ were married. With regard to education level, most (74.1\%) have reported complete high school or above; income has not followed education level; $46.1 \%$ have reported family income of up to two minimum wages and $60.8 \%$ have reported belonging to socioeconomic condition $\mathrm{C}$ (Table 1).

Table 1. Sociodemographic data of civil servants. Marataízes/ES

\begin{tabular}{|c|c|c|}
\hline Characteristics & $\mathrm{n}$ & $\%$ \\
\hline \multicolumn{3}{|l|}{ Gender } \\
\hline Male & 103 & 36.0 \\
\hline Female & 183 & 64.0 \\
\hline \multicolumn{3}{|l|}{ Age group (years) } \\
\hline $18-30$ & 63 & 22.0 \\
\hline $31-40$ & 123 & 43.0 \\
\hline $41-50$ & 80 & 28.0 \\
\hline 51 or above & 20 & 7.0 \\
\hline \multicolumn{3}{|l|}{ Marital status } \\
\hline Single & 59 & 20.6 \\
\hline Married & 175 & 61.2 \\
\hline Cohabitating & 32 & 11.2 \\
\hline Divorced & 20 & 7.0 \\
\hline \multicolumn{3}{|l|}{ Education level } \\
\hline Incomplete elementary school & 39 & 13.6 \\
\hline Complete elementary school & 21 & 7.4 \\
\hline Incomplete high school & 14 & 4.9 \\
\hline Complete high school & 95 & 33.2 \\
\hline Incomplete college & 41 & 14.3 \\
\hline Complete college & 76 & 26.6 \\
\hline \multicolumn{3}{|l|}{ Family income } \\
\hline Less than 1 minimum wage & 7 & 2.4 \\
\hline 1 to 2 minimum wages & 125 & 43.7 \\
\hline 3 to 5 minimum wages & 127 & 44.4 \\
\hline 6 to 10 minimum wages & 21 & 7.3 \\
\hline Above 10 minimum wages & 6 & 2.2 \\
\hline \multicolumn{3}{|l|}{ Socioeconomic condition } \\
\hline A & 10 & 3.5 \\
\hline $\mathrm{B}$ & 79 & 27.6 \\
\hline C & 174 & 60.8 \\
\hline $\mathrm{D}$ & 18 & 6.3 \\
\hline $\mathrm{E}$ & 5 & 1.8 \\
\hline Total & 286 & 100.0 \\
\hline
\end{tabular}


With regard to dentition, 84 (29.4\%) have reported no tooth loss, $201(70.3 \%)$ have reported at least one tooth loss and one employee $(0.3 \%)$ has reported being edentulous.

From participants reporting tooth loss, 119 (58.9\%) had lost posterior teeth, 14 (6.9\%) anterior teeth and $69(34.2 \%)$ posterior and anterior teeth. As to the reported need for removable partial prosthesis (RPP), 191 participants $(66.8 \%)$ have answered they did not need, $84(29.4 \%)$ have reported need and $11(3.8 \%)$ have refused to answer.

With regard to reported need for total prosthesis, 253 (88.5\%) have answered they did not need, $25(8.7 \%)$ have perceived the need and $8(2.8 \%)$ have refused to answer (Table 2$)$.

Prevalence of toothache was 57\%, considered high and enough to lead to the use of dental services in $39.9 \%$ of these employees. The use of public dental services $(47.7 \%)$ was very close to that recorded for private services $(44.6 \%)$. The number of employees $(6.2 \%)$ looking for a fake professional was surprising (Table 2).

The prevalence of reported absenteeism caused by toothache was $17.8 \%$, generating loss of up to one working day for $93.2 \%$. With regard to productivity, $27 \%$ of employees with toothache have reported that it has interfered with labor activities (Table 3).

With regard to variables gender, age group, socioeconomic condition (SEC), family income and education level, results have shown no statistically significant association with the

Table 2. Data on dental pain of civil servants. Marataízes/ES

\begin{tabular}{lcc}
\hline Characteristics & $\mathrm{n}$ & $\%$ \\
\hline Pain & 163 & 57.0 \\
Yes & 123 & 43.0 \\
No & & \\
Looked for dental assistance & 65 & 39.9 \\
Yes & 98 & 60.1 \\
No & & \\
Type of service & 31 & 47.7 \\
Health unit & 4 & 6.2 \\
Fake professional & 29 & 44.6 \\
Private & 1 & 1.5 \\
Other & & \\
Number of visits to dental service & 30 & 46.2 \\
Once & 18 & 27.6 \\
Twice & 17 & 26.2 \\
Three times or more & & \\
Reason for not using the serviced & 3 & 3.1 \\
Fear & 12 & 12.2 \\
Felt no need & 3 & 3.1 \\
Was not allowed & 1.0 \\
Lack of money & 46 & 46.9 \\
Could not schedule visit & 9 & 9.2 \\
Other reason & & \\
Has not justified & & \\
\hline
\end{tabular}

prevalence of toothache. When testing variable SEC, p value (0.054) was very close to nominal limit, showing potentially significant result (Table 4).

Prevalence of absenteeism was higher among employees of socioeconomic classes $\mathrm{C} / \mathrm{D} / \mathrm{E}(\mathrm{OR}=3.816$, CI $95 \%=$ $1.094 ; 13.333)$, that is, the chance of classes $\mathrm{C} / \mathrm{D} / \mathrm{E}$ individuals missing work due to toothache was 3.816 times higher as compared to that of classes A and B.

Workers with education level up to incomplete high school had 2.298 times more chance of missing work due to toothache $(\mathrm{OR}=2.298$, CI $95 \%=1.005 ; 5.255)$, as compared to those with higher level education (Table 5).

Table 3. Absenteeism data of civil servants. Marataízes/ES

\begin{tabular}{lcc}
\hline Characteristics & $\mathrm{n}$ & $\%$ \\
\hline Absence from work due to pain & 29 & 17.8 \\
$\quad$ Yes & 134 & 82.2 \\
$\quad$ No & & \\
Absence from work & 16 & 55.3 \\
$\quad$ One shift & 11 & 37.9 \\
One day & 2 & 6.8 \\
Two to three days & & \\
Productivity at work with toothache & 9 & 6.7 \\
$\quad$ Paid no attention to tasks & 8 & 6.0 \\
Postponed tasks to next Day & 10 & 7.5 \\
Failed to carry out tasks & 107 & 79.9 \\
Has not justified & & \\
\hline
\end{tabular}

Table 4. Data on dental pain and sociodemographic characteristics of civil servants. Marataízes/ES

\begin{tabular}{|c|c|c|c|c|c|c|}
\hline \multirow[t]{2}{*}{ Characteristics } & \multicolumn{2}{|c|}{ Pain } & \multicolumn{2}{|c|}{ No pain } & \multirow{2}{*}{$\begin{array}{c}\mathrm{p}- \\
\text { value }\end{array}$} & \multirow{2}{*}{$\begin{array}{l}\text { Odds } \\
\text { Ratio }\end{array}$} \\
\hline & $\mathrm{n}$ & $\%$ & $\mathrm{n}$ & $\%$ & & \\
\hline \multicolumn{7}{|l|}{ Gender } \\
\hline Male & 58 & 56.3 & 45 & 43.7 & 0.479 & \multirow{2}{*}{$\begin{array}{c}1.044 \\
0.641-1.700\end{array}$} \\
\hline Female & 105 & 57.4 & 78 & 42.6 & & \\
\hline \multicolumn{7}{|l|}{ Age group (years) } \\
\hline Up to 40 & 112 & 60.2 & 74 & 39.8 & 0.085 & \multirow{2}{*}{$\begin{array}{c}1.454 \\
0.891-2.373\end{array}$} \\
\hline 41 or above & 51 & 51.0 & 49 & 49.0 & & \\
\hline \multicolumn{7}{|c|}{ Socioeconomic class } \\
\hline A/B & 44 & 49.4 & 45 & 50.6 & 0.054 & \multirow{2}{*}{$\begin{array}{c}1.560 \\
0.942-2.583\end{array}$} \\
\hline $\mathrm{C} / \mathrm{D} / \mathrm{E}$ & 119 & 60.4 & 78 & 39.6 & & \\
\hline \multicolumn{7}{|l|}{ Family income } \\
\hline $\begin{array}{l}\text { Up to } 2 \\
\text { minimum wages }\end{array}$ & 76 & 57.6 & 56 & 42.4 & 0.474 & \multirow[t]{2}{*}{$\begin{array}{c}1.045 \\
0.653-1.672\end{array}$} \\
\hline $\begin{array}{l}\text { Above } 2 \\
\text { minimum wages }\end{array}$ & 87 & 56.5 & 67 & 43.5 & & \\
\hline \multicolumn{7}{|l|}{ Education level } \\
\hline $\begin{array}{l}\text { Incomplete high } \\
\text { school }\end{array}$ & 48 & 64.9 & 26 & 35.1 & 0.073 & \multirow[t]{2}{*}{$\begin{array}{c}1.557 \\
0.900-2.695\end{array}$} \\
\hline $\begin{array}{l}\text { Complete high } \\
\text { school or above }\end{array}$ & 115 & 54.2 & 97 & 45.8 & & \\
\hline
\end{tabular}


Table 5. Data on absenteeism due to toothache of employees of the local government of Marataízes/ES, 2009

\begin{tabular}{|c|c|c|c|c|c|c|}
\hline \multirow[t]{2}{*}{ Characteristics } & \multicolumn{2}{|c|}{$\begin{array}{c}\text { Absence } \\
\text { from } \\
\text { work }\end{array}$} & \multicolumn{2}{|c|}{$\begin{array}{c}\text { No } \\
\text { absence }\end{array}$} & \multirow[t]{2}{*}{$\begin{array}{c}\mathrm{p}- \\
\text { value }\end{array}$} & \multirow[t]{2}{*}{ Odds Ratio } \\
\hline & $\mathrm{n}$ & $\%$ & $\mathrm{n}$ & $\%$ & & \\
\hline \multicolumn{7}{|l|}{ Gender } \\
\hline Male & 10 & 17.2 & 48 & 82.8 & \multirow[t]{2}{*}{0.536} & 1.060 \\
\hline Female & 19 & 18.1 & 86 & 81.9 & & $0.456-2.463$ \\
\hline \multicolumn{7}{|l|}{ Age group (years) } \\
\hline Up to 40 & 23 & 20.5 & 89 & 79.5 & \multirow[t]{2}{*}{0.126} & 1.938 \\
\hline 41 or above & 6 & 11.8 & 45 & 88.2 & & $0.737-5.099$ \\
\hline \multicolumn{7}{|l|}{ Socioeconomic class } \\
\hline A/B & 3 & 6.8 & 41 & 93.2 & \multirow[t]{2}{*}{0.018} & 3.816 \\
\hline $\mathrm{C} / \mathrm{D} / \mathrm{E}$ & 26 & 21.8 & 93 & 78.2 & & $1.094-13.33$ \\
\hline \multicolumn{7}{|l|}{ Family income } \\
\hline $\begin{array}{l}\text { Up to } 2 \text { minimum } \\
\text { wages }\end{array}$ & 17 & 22.4 & 59 & 77.6 & \multirow[t]{2}{*}{0.111} & $\begin{array}{c}1.801 \\
0.798-4.064\end{array}$ \\
\hline $\begin{array}{l}\text { Above } 2 \\
\text { minimum wages }\end{array}$ & 12 & 13.8 & 75 & 86.2 & & \\
\hline \multicolumn{7}{|l|}{ Education level } \\
\hline $\begin{array}{l}\text { Incomplete high } \\
\text { school }\end{array}$ & 13 & 27.1 & 35 & 72.9 & \multirow[t]{2}{*}{0.040} & $\begin{array}{c}2.298 \\
1.005-5.255\end{array}$ \\
\hline $\begin{array}{l}\text { High school or } \\
\text { above }\end{array}$ & 16 & 13.9 & 99 & 86.1 & & \\
\hline \multicolumn{7}{|c|}{ Type of dental service } \\
\hline Health unit & 10 & 32.3 & 21 & 67.7 & \multirow[t]{2}{*}{0.405} & 1.323 \\
\hline Private/others & 9 & 26.5 & 25 & 73.5 & & $0.453-3.861$ \\
\hline \multicolumn{7}{|c|}{ Visits to dental service } \\
\hline Once & 6 & 20.0 & 24 & 80.0 & \multirow[t]{2}{*}{0.107} & 2.364 \\
\hline More than once & 13 & 37.1 & 22 & 62.9 & & $0.765-7.299$ \\
\hline
\end{tabular}

\section{DISCUSSION}

Dental pain prevalence among participants of this study was $57.0 \%$ and was considered high; however, it was similar to other results found in Espírito Santo, of 43\% among employees of the local government of Venda Nova do Imigrante ${ }^{8}$ and of $46.7 \%$ among employees of a food company in Linhares ${ }^{9}$. International studies have also found similar results ${ }^{10}$, of $51.9 \%$ among Australian employees ${ }^{11}$, and of $43.6 \%$ among employees of two Malaysian industries. Some Brazilian studies have shown lower prevalence: $33.7 \%$ among students aged from 12 to 13 years in Florianópolis-SC ${ }^{12}$; 28\% among metallurgical and mechanical employees in Xanxerê-SC ${ }^{13} ; 20.7 \%$ among employees of the Municipal Urban Cleaning Department of Porto Alegre-RS ${ }^{14}$.

Such comparisons are impaired by variations among age groups, observation intervals (last two weeks, six months or even 12 months), and different regions within Brazil and worldwide. It is important to stress that methodological aspects of future epidemiological studies on the subject should be standardized to provide more reliable comparisons ${ }^{15}$.

In our study, toothache was not associated to gender, being in agreement with other studies ${ }^{16,17}$. There are reports showing that males have higher chance of having dental pain ${ }^{18,19}$. Classes $\mathrm{C} / \mathrm{D} / \mathrm{E}$ workers had $56 \%$ more chance of experiencing toothache as compared to those of more privileged classes. Extensive literature has shown a higher prevalence of tooth decay and its consequences in more destituted classes. Worst indices worldwide are found in regions of social deprivation. Social status is the fundamental cause of the disease, because it mediates the access to society resources and this determines the access to all points of the causal chain of the health/disease process ${ }^{20}$. Most studies on oral health social determinants associate social class, socioeconomic class, income and education level to oral health conditions ${ }^{21}$.

Our study has not found statistically significant difference in family income and the prevalence of dental pain, being in disagreement with studies showing that low income families were more susceptible to dental pain ${ }^{12,17,18,22,23}$. A possible explanation to this finding is that, in our study, Brazilian salary inequality was not reproduced, having salary proximity at the cutoff point for the analysis of the variable.

Absenteeism due to dental pain in our study was $17.8 \%$, very close to results found in Espírito Santo and Brazil ${ }^{15,19}$. This study has shown that $20.0 \%$ of employees with toothache have reported loss of productivity during their labor activities due to poor attention or mistakes when carrying out tasks. This is important not only due to decreased productivity, but also to the increased risk of labor accidents. Gemeli ${ }^{24}$ has investigated labor accidents and has found that in $11.0 \%$ of cases, respondents have reported dental pain on the day of the accident suggesting possible interference of dental pain on workers' attention and concentration.

Brazil is a champion in labor accident statistics. It is always important to remind that such statistics reflect accidents recorded by Social Security. It estimated that in Brazil there is still a high rate of underreporting of accidents ${ }^{25}$.

Our study has observed that $39.9 \%$ of participants with dental pain have looked for dental services. Most widely used type of service was public service $(47.7 \%)$, followed by private service $(40 \%)$. Since sample is made up of municipal employees, this could, in a way, have motivated the use of public oral health services. But even with large part (46\%) reporting family income of up to two minimum wages, a large percentage has used the private system. Studies are needed to understand oral health values and beliefs and the existence of barriers which may affect the use of public services. Studies are also needed to understand the fact that $6.2 \%$ of workers have looked for a fake professional, although being employees of a local government of the Southeastern Region where dental services are available and which, according to the Brazilian Constitution $^{26}$, should assure access to all citizens, especially in urgent cases ${ }^{27}$.

The use of oral health services is determined by several variables with different prediction power ${ }^{28}$. Several studies have shown perception of need as the characteristic with highest explanation power for the search for dental assistance. Dental pain is not always enough to motivate a visit to the dental service $^{29}$. 
From workers reporting toothache in the last six months and not having looked for oral health services, $46.9 \%$ have not perceived the need and $12.0 \%$ failed to do it due to lack of money, which may suggest a lack of third shift dental assistance in the public service or not having been waived for treatment. The high prevalence of pain and absenteeism found in this study justifies the implementation of actions, going from the creation of health public service third shift to the insertion of Ds in the company ${ }^{8}$.

One cannot discard the possibility of self-medication, very popular and concerning procedure in Brazil for being inadequately and abusively done and, most of the times, with drugs subject to medical prescription ${ }^{30}$. Self-medication is also very popular in other countries. With poorly-structured health system, going to the pharmacy is the first option to solve a health-related problem. Simpler and more commonly used drugs, such as analgesics, are available in pharmacies and even in supermarkets, may be purchased without medical prescription and are the most widely used as self-medication ${ }^{31,32}$.

Our study has found that employees with socioeconomic condition $\mathrm{C} / \mathrm{D} / \mathrm{E}$ had almost four times more chance of missing work due to dental pain, as compared to classes A/B. Mentioned Brazilian studies have not considered this variable; international studies use a different tool to classify subjects according to social status, thus making comparisons difficult. Our results have shown that employees with lower education level had 2.3 times more chance of missing work due to toothache. These results are similar and comparable to other studies ${ }^{8,18,33}$.

\section{CONCLUSION}

Our study has observed high prevalence of toothache generating absenteeism, with higher frequency among workers from less privileged economic classes and with lower education levels.

Strategies directed to health promotion and to better access to dental services certainly will be able to decrease observed frequencies.

\section{REFERENCES}

1. Brasil. Ministério da Saúde. Portaria no 19/GM. Brasília, 3 jan. 2002. Disponível em: http://dtr2001.saude.gov.br/sas/Portarias/Port2005/GM/GM-19.htm. Acessado em: 10 de novembro de 2009

2. Yano SR, Santana VS. Faltas ao trabalho por problemas de saúde na indústria. Cad Saude Publica. 2012;28(5):945-54

3. Aguiar GA, Oliveira JR. Absenteísmo: suas principais causas e consequências em uma empresa no ramo de saúde. Rev Ciências Gerenciais. 2009;8(18):95-113.

4. Sheiham A. Oral health, general health and quality of life. Bull World Health Organ. 2005;83(9):644.

5. Brasil. Câmara dos Deputados. Comissáo de Trabalho, de Administraçáo e Serviço Público, Brasília. Projeto de Lei, PL no 957/2003. Disponível em: http://www.camara. gov.br. Acessado em: 02 de setembro de 2008

6. Brasil. Câmara dos Deputados. Comissão de Desenvolvimento Econômico, Indústria e Comércio. Brasília. Projeto de Lei, PL n.o 422/2007. Disponível em: http://www. camara.gov.br. Acessado em: 02 de setembro de 2008.

7. Medeiros UV, Abreu CM. Protocolo de promoçáo de saúde bucal em empresas. Rev Bras Odontol. 2006;63 (1/2):29-32.

8. Miotto MH, Silotti JC, Barcellos LA. Dor dentária como motivo de absenteísmo em uma populaçáo de trabalhadores. Cien Saude Colet. 2012;17(5):1355-63.

9. Miotto MH, Barcellos LA, Lopes ZV. Dor de dente como preditor de absenteísmo em trabalhadores de uma indústria de sucos da Regiāo Sudeste do Brasil. Cienc Saúde Colet. 2013;18(11):3183-90

10. Sanders AE, Spencer AJ. Job characteristics and the subjective oral health of Australian workers. Aust N Z J Public Health. 2004;28(3):259-66.

11. Jaafar N, Razak IA, Zain RB. The impact of oral and facial pain in an industrial population. Ann Acad Med Singapore. 1989;18(5):553-5.

12. Nomura LH, Bastos, JL, Peres MA. Prevalência de dor de dente e associaçáo com cárie e condiçốes socioeconômicas em escolares, sul do Brasil, 2002. Braz Oral Res. 2004;18(2):134-40.

13. Lacerda JT, Traebert J, Zambenedetti ML. Dor orofacial e absenteísmo em trabalhadores da indústria metalúrgica e mecânica. Saúde Soc. 2008;17(4):182-91.

14. Gomes AS, Abegg C. O impacto odontológico no desempenho diário dos trabalhadores do departamento municipal de limpeza urbana de Porto Alegre, Rio Grande do Sul, Brasil. Cad Saúde Pública. 2007;23(7):1707-14.

15. Nardi A, Michel-Crosato M, Biazevic MG, Cosato E, Pizzatto E, Queluz DP. Relationship between orofacial pain and absenteeism among workers in Southern Brasil. Braz J Oral Sci. 2009;8(1):50-4.

16. Locker D, Grushka M. The Impact dental and facial pain. J Dent Res. 1987;66(9):1414-7.

17. Pau AK, Croucher R, Marcenes W. Prevalence estimates and associated factors for dental pain: a review. Oral Health Prev Dent. 2003;1(3):209-20.

18. Alexandre GC, Nadanovsky P, Lopes CS, Faerstein E. Prevalência e fatores associados à ocorrência da dor de dente que impediu a realizaçăo de tarefas habituais em uma populaçăo de funcionários públicos no Rio de Janeiro, Brasil. Cad Saúde Pública. 2006;22(5):1073-8

19. Nardi A, Michel-Crosato E, Biazevic MGH. Dores dental e facial em trabalhadores do sul do Brasil, 2003. Rev Odontol UNESP. 2006;35(1):81-7.

20. Graham H. Social determinants and their unequal distribution: clarifying policy understandings. Milbank Q. 2004;82(1):101-24.

21. Newton JT, Bower EJ. The social determinants of oral health: new approaches to conceptualizing and researching complex causal networks. Community Dent Oral Epidemiol. 2005;33(1):25-34

22. Bastos JL, Nomura LH, Peres MA. Dor de dente e sua relação com condiçóes sócio-econômicas e cárie dentária em adultos jovens do sexo masculino no Sul do Brasil. Cad Saúde Pública. 2005;21(5):1416-23

23. Goes PSA, Sheiham A, Watt RG, Hardy R. The prevalence and severity of dental pain in Brazilian 14-15 years old schoolchildren. Community Dental Health. 2007; 24 : 217-24, 2007

24. Gemeli TR. Aplicaçáo e análise de metodologia investigatória de causalidade entre morbidez odontológica e acidentes de trabalho. Disponível em: http://www.saude. sc.gov.br. Acesso em: 20 de fevereiro de 2009].

25. Binder MCP, Almeida IM. Acidentes de trabalho: acaso ou descaso. In: Mendes R, (editor). Patologia do trabalho. São Paulo: Atheneu; 2005. 769-810p.

26. Brasil. Constituição [da] República Federativa do Brasil. Brasília: Senado Federal, 1988.

27. Brasil. Ministério da Saúde. Diretrizes da Política Nacional de Saúde Bucal. 2004 Disponível em: http//www.saude.ms.gov.br. Acesso em 13 de junho de 2010.

28. Baldani MH, Brito WH, Lawder JA, Mendes YB, da Silva F de F, Antunes JL. Determinantes individuais da utilizaçáo de serviços odontológicos por adultos e idosos de baixa renda. Rev Bras Epidemiol. 2010;13(1):150-62.

29. Reisine ST. Dental disease and work loss. J Dent Res. 1984;63(9):1158-61.

30. Mastroianni P de C, Lucchetta RC, Sarra J dos R, Galduróz JC. Estoque doméstico e uso de medicamentos em uma populaçáo cadastrada na estratégia saúde da família no Brasil. Rev Panam Salud Publica. 2011;29(5):358-64.

31. Loyola Filho AI, Uchoa E, Guerra HL, Firmo JO, Lima-Costa MF. Prevalência e fatores associados à automedicação: resultados do projeto Bambuí. Rev Saúde Pública. 2002;36(1):55-62.

32. Schmid B, Bernal R, Silva NN. Automedicação em adultos de baixa renda do municí pio de Săo Paulo. Rev Saude Publica. 2010;44(6):1039-45.

33. Reisine ST, Miller J. A longitudinal study of work loss related to dental diseases. Soc Sci Med. 1985;21(12):1309-14. 